\title{
Supraclavicular Artery Island Flap: Relation Between Length and Distal End Necrosis
}

\author{
Hemin Sheriff, MD, PhD ${ }^{1,4 *}$; Carmen Vega Garcia, MD, PhD²; Suzan Jaber, FICMS, EBOPRAS ${ }^{1,3}$; \\ Débora Bernárdez Ojea, MD, PhD²; Shokha Shahab Kareem, MBChB'; \\ Manuel Fernandez Garrido, MD, PhD²; Jaume Masia, MD, PhD² \\ Department of Surgery, College of Medicine, University of Sulaimani, Sulaymaniyah, Iraq \\ Department of Plastic Surgery, Hospital de Sant Pau i de la Santa Creu, Barcelona, Catalonia, Spain \\ ${ }^{3}$ Department of Plastic Surgery, Shar Hospital, Sulaymaniyah, Iraq \\ ${ }^{4}$ Department of Plastic Surgery and Burns, Sulaymaniyah Teaching Hospital, Sulaymaniyah, Iraq
}

\begin{abstract}
Background: Supraclavicular flap is an excellent fasciocutaneous flap for head and neck reconstruction due to its close color and texture match. In general, long flaps are required, but with the risk of distal necrosis. The aim of this study is to assess the relationship between the length and distal end necrosis of the supraclavicular flap.

Methods: Between 2013 and 2017, 21 patients underwent head and neck reconstruction surgery, in which 25 supraclavicular flaps were used. In 12 cases, the flaps were used for reconstruction following release and excision of burn contractures, whereas the remaining 9 patients had flaps following wide excision of tumors. Different imaging techniques were used to facilitate the design and guide the dissection of the flap, and modification procedures were performed to prolong the survival length of the flaps.

Results: The length of the 25 flaps used varied according to the patient's needs. In average, the length ranged from $12-35 \mathrm{~cm}$ with a mean length of $20.76 \mathrm{~cm}$. There was no total flap loss; however, 3 of the flaps $(12 \%)$ resulted in distal end necrosis. All the flaps with distal necrosis had a length of $23 \mathrm{~cm}$ or more regardless of whether the modification procedures were performed or not, while the flaps with length below $23 \mathrm{~cm}$ had no necrosis (14 flaps).

Conclusion: The distal survival of the supraclavicular artery island flap is reliable up to $22 \mathrm{~cm}$, but the flaps above that size will increase the risk of distal necrosis with or without modification procedures.
\end{abstract}

\section{Introduction}

The supraclavicular flap has gained popularity in recent years as a reliable and easily harvested flap, which is ideal for head and neck reconstruction. The flap is based off an axial vessel branching from the thyrocervical trunk or transverse cervical artery. The color match, thinness, pliability, and the hair-free skin of supraclavicular artery flap parallel that of the head and neck region and provide a superior cosmetic outcome when compared to free tissue transfer flaps from the other regions such as the forearm, abdomen, or thigh [1-3].

In the year 1842, Thomas Mutter in Philadelphia described a random flap in the shoulder region [3-5]. In 1903, Toldt, an anatomist, first illustrated and named the vessel as arteria cervicalis superficialis. It originates from the thyrocervical trunk exiting between the trapezius and sternocleidomastoid muscles [2].

Kazanjian and Converse performed the first clinical application of a flap from the shoulder area in 1949 and they named it as "in charretera flap" or acromial flap $[3,6,7]$. The supraclavicular flap was first described by Lamberty in 1979 as an axial pattern fasciocutaneous flap [8].

In 1983, Lamberty and Cormack, in an anatomical study on cadavers, found a vessel cephalad to the clavicular insertion of the trapezius muscle and they named it as the supraclavicular artery [9]. At the beginning of beginning in the 1990s, Pallua et al. "rediscovered" this flap and popularized its use by performing detailed anatomical studies examining the vascularity of what is known today as the supraclavicular island flap $[10,11]$. They published several clinical series of supraclavicular flaps for reconstruction of post-burn neck contracture, and also in oncologic head and neck reconstruction. They found the flap safe and reliable for immediate resurfacing of cervical defects [5,11-13].

Di Benedetto et al. in 2005 reported this flap as reliable for covering intraoral defects after oncologic resection [14]. Epps et al. and Emerick et al. described the use of supraclavicular flap for the restoration of the parotidectomy defects $[15,16]$. Chiu et al. described the use of the supraclavicular flap for functional pharyngeal reconstruction [17].

In the past decade, this flap has been widely used and discussed [1820]. Anatomical studies supporting its use have been performed [21-23]. The sensate [24], the pre-expanded $[13,25,26]$, the delayed $[8,27]$, the prefabricated [27], the superthin $[13,28]$, the folded [29,30], and the bilobed versions [30-32] of supraclavicular flap have also been developed.

The use of supraclavicular flap for head and neck reconstruction was well described in many articles $[1,2,4,11-17,19,20,23-26,28,29,31,33-40]$ with a special focus on the length of flaps and their rate of necrosis. The aim of this study is to check the relation between the length and distal end necrosis of supraclavicular flap.

\section{Methods}

In the time frame between July 2013 and February 2017, 21 patients underwent reconstruction with supraclavicular island flap for head and neck defects following the release and excision of burn contractures and wide excision of tumors.

This study was conducted in the Burns and Plastic Surgery Department in Sulaimaniah Teaching Hospitals in Sulaimani, Iraq, and the Plastic Surgery Departments of Hospital de la Santa Creu i Sant Pau and Hospital del Mar in Barcelona, Spain. The patients who required reconstruction with pedicled supraclavicular island flaps for head and neck defects in both centers were included in this study. None of the supraclavicular island flaps were used for aerodigestive tract reconstruction.

Twenty-five supraclavicular artery island flaps were used for 21 patients. From the 21 patients that underwent reconstruction, 12 cases had 
Table 1. Patient Characteristics

\begin{tabular}{|c|c|c|c|c|c|c|c|}
\hline No. & Age & Sex & Side & $\begin{array}{l}\text { Dimensions of } \\
\text { the Flap }(\mathrm{cm})\end{array}$ & Defect Type and Site & $\begin{array}{l}\text { Distal End } \\
\text { Necrosis }(\mathrm{cm})\end{array}$ & $\begin{array}{l}\text { Imaging Tests or Preliminary Procedures } \\
\text { (Delay or Tissue Expanders) }\end{array}$ \\
\hline 1 & 53 & M & L & $7 \times 14$ & Burn contracture in neck & No & $\mathrm{HHD}$ \\
\hline 2 & 22 & M & $\begin{array}{l}R \\
L\end{array}$ & $\begin{array}{l}7 \times 15 \\
7 \times 15\end{array}$ & Burn contracture in neck & $\begin{array}{l}\text { No } \\
\text { No }\end{array}$ & $\begin{array}{l}\mathrm{HHD} \\
\mathrm{HHD}\end{array}$ \\
\hline 3 & 35 & $\mathrm{~F}$ & $\begin{array}{l}R \\
L\end{array}$ & $\begin{array}{c}8 \times 23 \\
10 \times 25\end{array}$ & Burn contracture in neck & $\begin{array}{c}\text { No } \\
\text { Yes, } 2.5 \mathrm{~cm}\end{array}$ & $\begin{array}{c}H H D \\
H H D \text {, angiogram, tissue expander }\end{array}$ \\
\hline 4 & 27 & $\mathrm{~F}$ & $\mathrm{R}$ & $8 \times 25$ & Burn contracture in neck & No & HHD \\
\hline 5 & 50 & $\mathrm{~F}$ & L & $11 \times 30$ & $\begin{array}{l}\text { Wide excision of recurrent SCC } \\
\text { in left temple }\end{array}$ & No & HHD, delay procedure \\
\hline 6 & 40 & $\mathrm{~F}$ & $\mathrm{R}$ & $6 \times 12$ & Burn contracture in neck & No & HHD \\
\hline 7 & 37 & $\mathrm{~F}$ & L & $5 \times 12$ & Burn contracture in neck & No & $\mathrm{HHD}$ \\
\hline 8 & 26 & $\mathrm{~F}$ & $\mathrm{R}$ & $10 \times 35$ & Burn contracture in neck & Yes, $6 \mathrm{~cm}$ & HHD, delay procedure \\
\hline 9 & 30 & $\mathrm{~F}$ & L & $9 \times 25$ & Burn contracture in neck & No & HHD, tissue expander + delay procedure \\
\hline 10 & 55 & M & L & $8 \times 17$ & Burn contracture in neck & No & HHD \\
\hline 11 & 27 & $\mathrm{~F}$ & L & $8 \times 18$ & Burn contracture in neck & No & $\mathrm{HHD}$ \\
\hline 12 & 35 & $\mathrm{~F}$ & $\begin{array}{l}\mathrm{R} \\
\mathrm{L}\end{array}$ & $\begin{array}{l}7 \times 15 \\
7 \times 17\end{array}$ & Burn contracture in neck & $\begin{array}{l}\text { No } \\
\text { No }\end{array}$ & $\begin{array}{l}\mathrm{HHD} \\
\mathrm{HHD}\end{array}$ \\
\hline 13 & 23 & $\mathrm{~F}$ & $\begin{array}{l}\mathrm{R} \\
\mathrm{L}\end{array}$ & $\begin{array}{l}10 \times 25 \\
11 \times 27\end{array}$ & Burn contracture in neck & $\begin{array}{l}\text { No } \\
\text { No }\end{array}$ & $\begin{array}{l}\text { HHD, tissue expander } \\
\text { HHD, tissue expander }\end{array}$ \\
\hline 14 & 76 & $\mathrm{~F}$ & L & $8.5 \times 27$ & Basal cell carcinoma in neck & No & HHD, preoperative ICG \\
\hline 15 & 50 & $\mathrm{~F}$ & $\mathrm{R}$ & $6 \times 17$ & $\begin{array}{l}\text { Mastoid exposition } \\
\text { (complication of neurosurgery) }\end{array}$ & No & $\mathrm{HHD}$, angio-CT \\
\hline 16 & 85 & $\mathrm{~F}$ & $\mathrm{R}$ & $9 \times 21$ & SCC intraparotid metastasis & No & HHD, intraoperative ICG \\
\hline 17 & 70 & $\mathrm{~F}$ & L & $8 \times 23$ & $\begin{array}{l}\text { Malignant tumor of parotid } \\
\text { gland }\end{array}$ & Yes, $2 \mathrm{~cm}$ & HHD, intraoperative ICG \\
\hline 18 & 76 & $\mathrm{~F}$ & L & $7 \times 16$ & SCC in neck & No & Intraoperative ICG \\
\hline 19 & 78 & M & $\mathrm{R}$ & $10 \times 27$ & SCC intraparotid metastasis & No & $\mathrm{HHD}$ \\
\hline 20 & 71 & M & $\mathrm{R}$ & $7 \times 20$ & $\begin{array}{l}\text { Dermatofibrosarcoma } \\
\text { protuberans in neck }\end{array}$ & No & HHD, intraoperative ICG \\
\hline 21 & 49 & M & L & $7 \times 18$ & Sarcoma metastasis in neck & No & $\mathrm{HHD}$ \\
\hline
\end{tabular}

$\mathrm{CT}$, computed tomography; CTA, computed tomography angiography; F, female; HHD, handheld doppler; ICG, indocyanine green; ICGA, indocyanine green fluorescent angiograms; L, left; M, male; R, right; SCC, squamous cell carcinoma.

post-burn neck contractures and scarring, which were excised and the defects were then reconstructed using the supraclavicular flap, whereas, the other 9 patients underwent supraclavicular flap reconstruction for the defects following wide excision of head tumors.

Smoking could be a factor that might affect the vascularity of the flaps. In this study, it was noted that all the male patients were ex-smokers or they had quit smoking prior to the operations, whereas, all the female patients were non-smokers.

All the surgical procedures, including the flap harvest and the reconstruction, were performed under general anesthesia. Different imaging techniques such as Hand-held Doppler, computerized tomography angiogram, fluoroscopy angiogram, and Indocyanine green angiogram were used in the preoperative or intraoperative stage for some patients in order to localize or map the pedicle (Table 1). In addition, modification techniques such as delay procedures and tissue expansion were also performed as a separate procedure in 6 flaps when more length was required, aiming to improve distal vascularity and facilitate donor site closure.

Supraclavicular artery island flap dissection started from distal to proximal edge, incising the inferior border of the flap as an exploratory incision. The dissection followed in a subfascial plane until the supracla- vicular pedicle was identified. Then, the superior incision was completed in order to raise the skin paddle. Supraclavicular pedicle isolation, usually, was not necessary to transpose the flap to the defect. Clavicle periosteum elevation or clavicle bone division was unnecessary.

Depending on the skin laxity or the reconstructive demands, tunnelization or depithelization of the neck skin was chosen. Depithelization of a part of the skin paddle is necessary when the tunnelization is performed to transpose the flap to the defect. It may be necessary to do a book incision in the neck skin if the tunnelization puts too much tension on the flap.

\section{Results}

A total of 25 supraclavicular artery island flaps were used for 21 patients with head and neck defects. Results of the study are shown in Table 1.

The procedure was performed in 15 female and 6 male patients, the mean age of the patients was 48.3 years. Four patients had bilateral flap reconstruction. Eleven flaps were harvested from the right side of the neck, whereas the remaining 14 flaps were taken from the left side.

The size of the supraclavicular flaps varied in length and width according to the patient's needs. On average, the length ranged from 12 to $35 \mathrm{~cm}$, with a mean length of $20.76 \mathrm{~cm}$ (standard deviation 6.01), whereas 
the width of the flaps ranged from 5 to $11 \mathrm{~cm}$ resulting in a mean width of $8.06 \mathrm{~cm}$ (standard deviation 1.59). Donor sites were directly closed in 20 flaps, but five cases (No. 1, 5, 9, 14, and 19) required split-thickness skin grafting in the area that was not possible to be closed directly.

All the flaps had distal viability after inset. There was no flap loss, but 3 flaps resulted in distal end necrosis (12\%). Four cases (No. 3, 5, 8, and 17 in Table 1) had distal flap congestion during the early preoperative stage. Salvage measures were quickly established. Dressings or distal stitches were removed in order to avoid any tension (cases 5 and 8). Local warm measurements plus application of local heparin gel every 8 hours were performed to increase the distal perfusion of the flap in the 4 cases.

Consequently, the vascularity of case No. 5 improved and distal closure was performed in 3 days. The other 3 flaps resulted in distal necrosis and they were managed according to their magnitude of necrosis. Two flaps with a small necrosis $(2$ and $2.5 \mathrm{~cm}$ ) were managed with dressings and secondary healing without sequelae, while the flap with bigger necrosis $(6 \mathrm{~cm})$ required debridement and approximations for closure.

\section{Case 1 (No. 15 in Table 1)}

50-year-old-female, required debridement of osteomyelitic mastoid bone as a complication of pontocerebellar angle meningioma approach (Figure 1A). Supraclavicular flap with $17 \times 6 \mathrm{~cm}$ skin paddle was used for bone coverage (Figure 1B and 1C).

\section{Case 2 (No. 3 in Table 1)}

35-year-old-female, post-burn hypertrophic scar and contracture on the neck and chest (Figure 2A). Three surgical procedures at different time were performed. The first surgical procedure was a partial excision of the neck scar and an $8 \times 23 \mathrm{~cm}$ right supraclavicular flap was used to fill the defect. The second procedure included a left pre-expanded supraclavicular flap and also tissue expander colocation under the right supraclavicular flap in the neck (Figure 2B). The third procedure included the excision of the remaining scar, expanders removed, $10 \times 25 \mathrm{~cm}$ left supraclavicular flap raised, both flap inset done, and donor sites were closed directly (Figure 2C and 2D). Further scar revision and Z plasty in the neck were performed as a separate minor procedure.

\section{Case 3 (No. 5 in Table 1)}

50-year-old-female with a fourth recurrence of squamous cell carcinoma (SCC) of the scalp and temple, involved left temporo parietal area and left auricle (Figure $3 \mathrm{~A}$ ). The CT scan showed infiltration of the outer table of the skull. A two-stage surgical procedure was planned. In the first surgical session, a flap of $11 \mathrm{~cm} \times 30 \mathrm{~cm}$ was delayed to increase the survival length of the flap through the delay phenomena. In the second stage (3 weeks later), a multidisciplinary team of neurosurgeons, otolaryngologists, and plastic surgeons performed wide tumor excision including the auricle and part of the skull bone, and the defect was reconstructed with a supraclavicular flap of $11 \mathrm{~cm} \times 30 \mathrm{~cm}$, and the donor site was covered with a split-thickness skin graft (Figure 3B, 3C, and 3D).
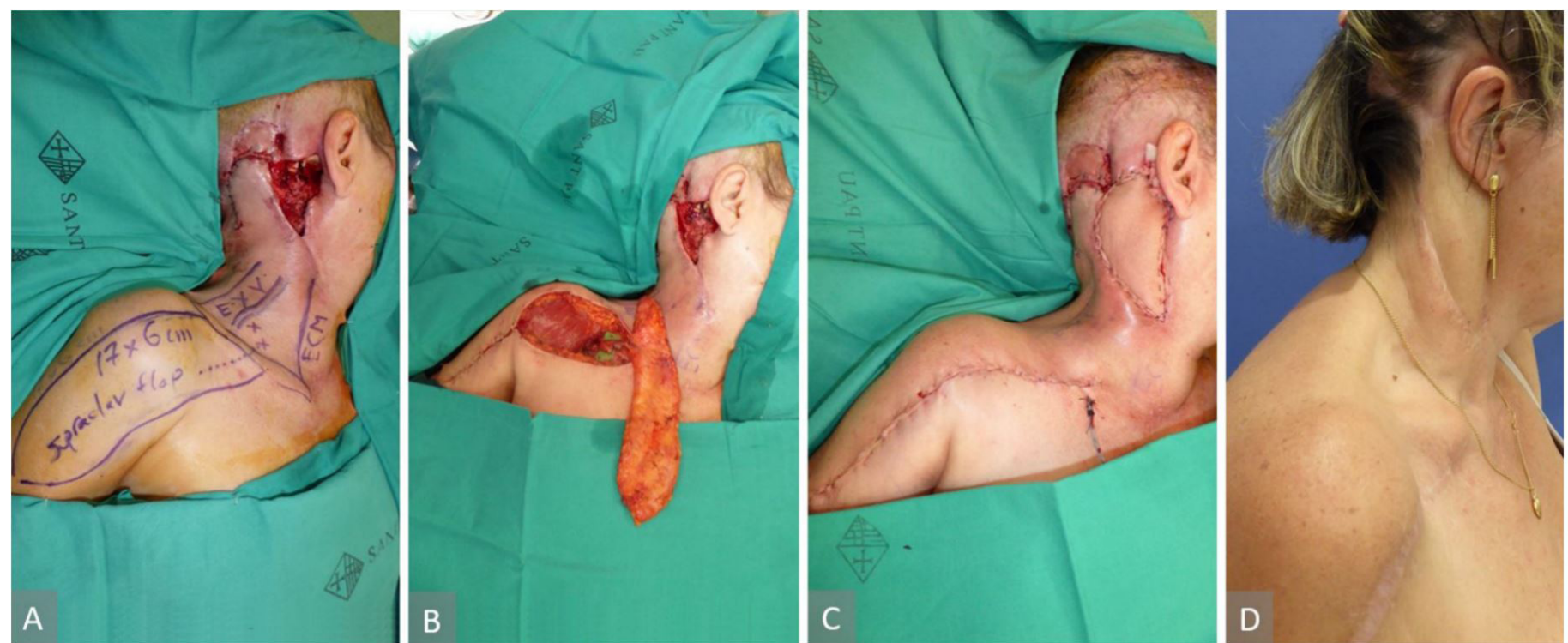

Figure 1. (A) Intraoperative view of the defect and the right supraclavicular flap designed. (B) Flap raised and the supraclavicular vessel isolated on the green background. (C) The flap inset done and the donor site closed directly. (D) Six-month postoperative result.
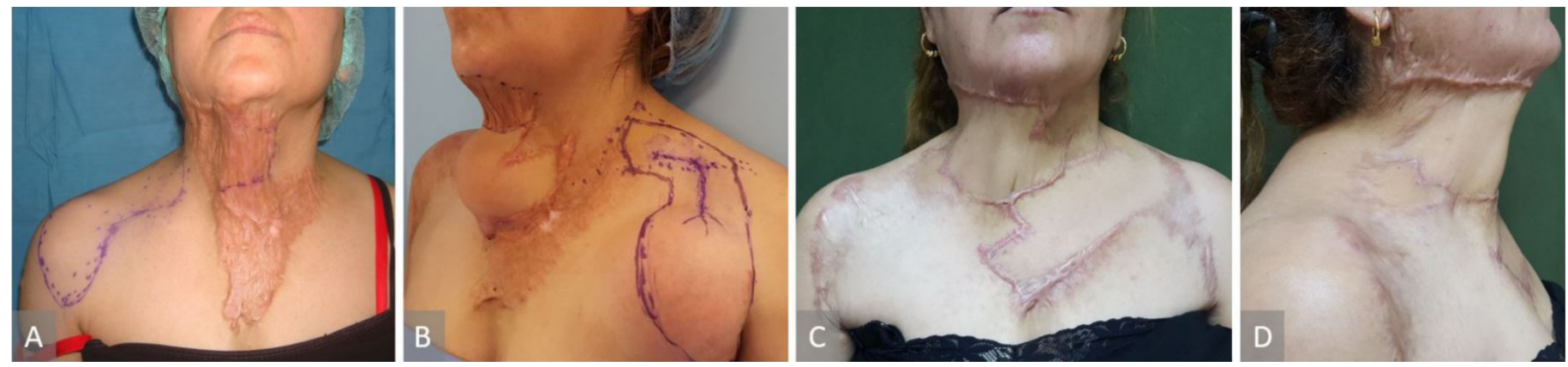

Figure 2. (A) Post-burn hypertrophic scar and contracture on the neck and chest. (B) Left pre-expanded supraclavicular flap and also tissue expander colocation under the right supraclavicular flap in the neck. (C) Post-operative view of the neck reconstruction with right and left supraclavicular flaps and the donor site closed primarily. (D) Post-operative view of the neck reconstruction with right and left supraclavicular flaps and the donor site closed primarily. 


\section{Case 4 (No. 9 in Table 1)}

30-year-old-female with post burn neck contracture (Figure 4A). A pre-expanded and delayed left supraclavicular flap of $9 \times 25 \mathrm{~cm}$ was used for reconstruction after the neck scar excision (Figure 4B, 4C, and 4D).

\section{Case 5 (No. 14 in Table 1)}

6-year-old-female with Cluster A disease and local advanced basal cell carcinoma in the left cheek (Figure 5A). The tumor was widely excised and the defect reconstructed with $27 \times 8.5 \mathrm{~cm}$ supraclavicular flap. Intraoperative ICG evaluation was performed to mark the pedicle and design the flap. The donor site was closed with a split-thickness skin graft and the flap completely survived (Figure 5B, 5C, and 5D).

\section{Discussion}

The results of this study have been analyzed to see the relationship between the flap length and distal end necrosis. According to the data obtained in the results section of this report, the distal end vascularity of the supraclavicular artery island flap was reliable up to $22 \mathrm{~cm}$, but the flaps with the size of $23 \mathrm{~cm}$ and above increased the risk of distal necrosis, regardless of whether the modification procedures were performed or not. Due to the presence of modification procedures in 6 flaps above 23 $\mathrm{cm}$ length, the statistical analysis couldn't be reported without bias as the group of the flaps above $23 \mathrm{~cm}$ was nonhomogeneous.
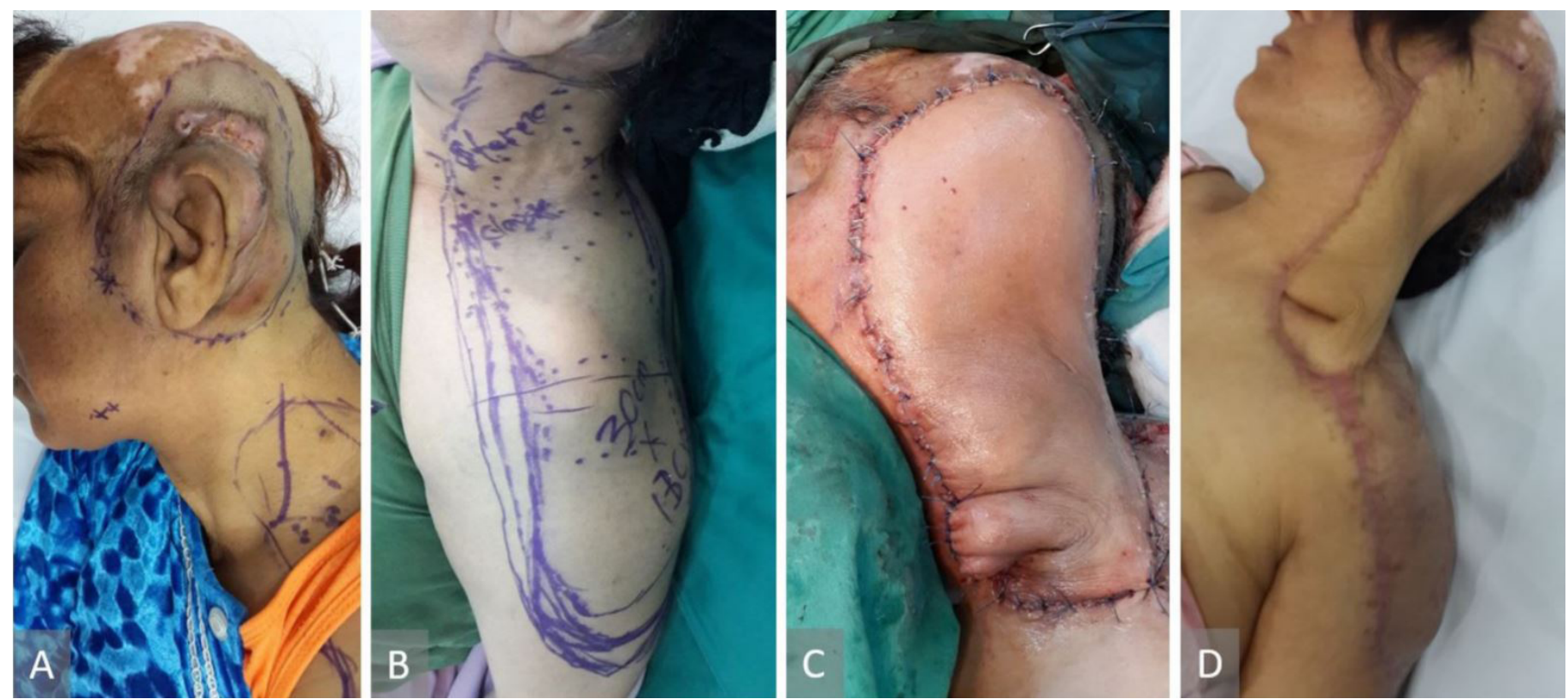

Figure 3. (A) Squamous cell carcinoma of the scalp and temple, involved left temporoparietal area and left auricle. (B) The supraclavicular flap of $30 \times 11$ $\mathrm{cm}$ marked to be delayed. (C) The flap inset. (D) Three-month postoperative view.
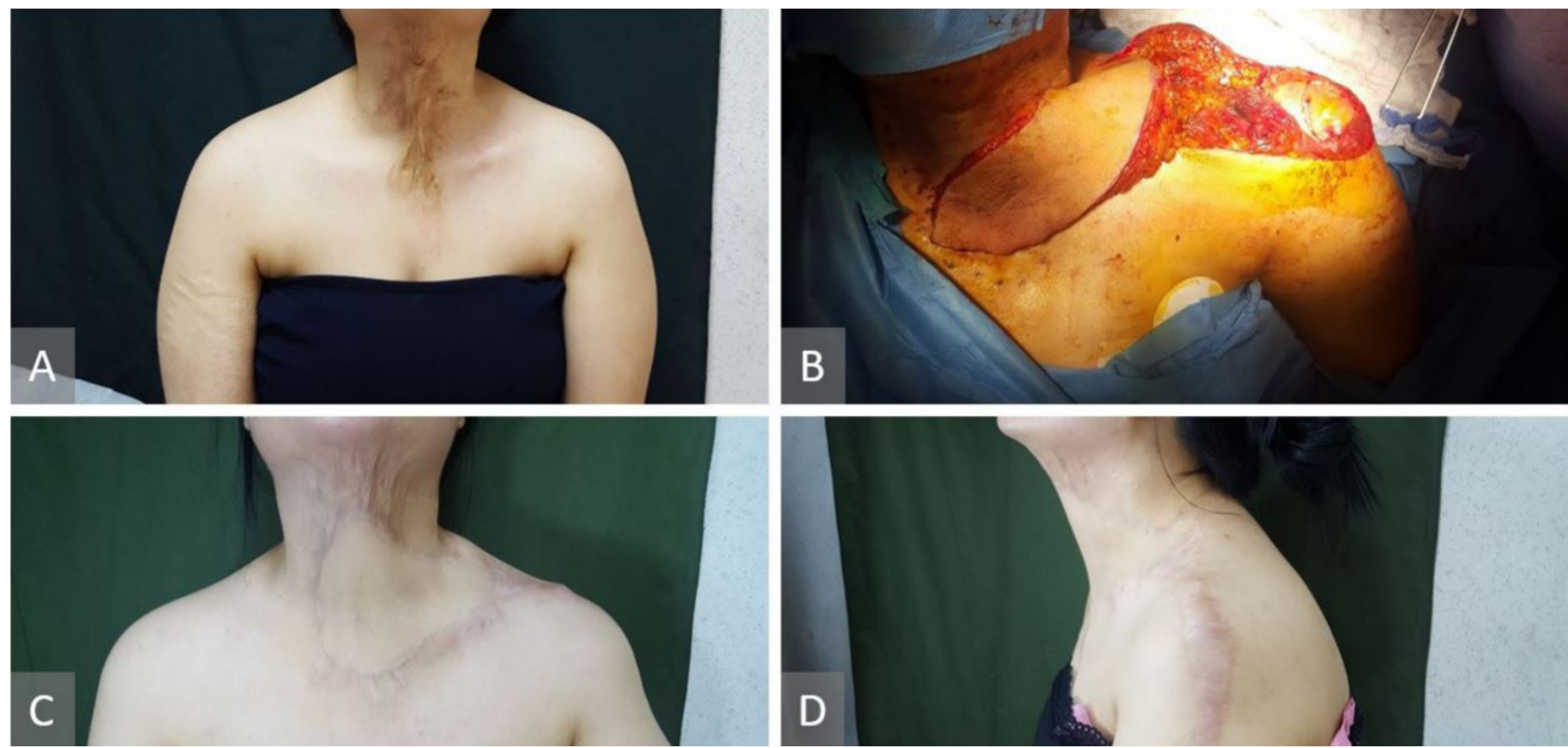

Figure 4. (A) Post burn neck contracture. (B) Pre-expanded and delayed left supraclavicular flap of $9 \times 25 \mathrm{~cm}$ has been raised for neck defect reconstruction after the neck scar excision. (C) Six-month postoperative view. (D) Six-month postoperative view. 

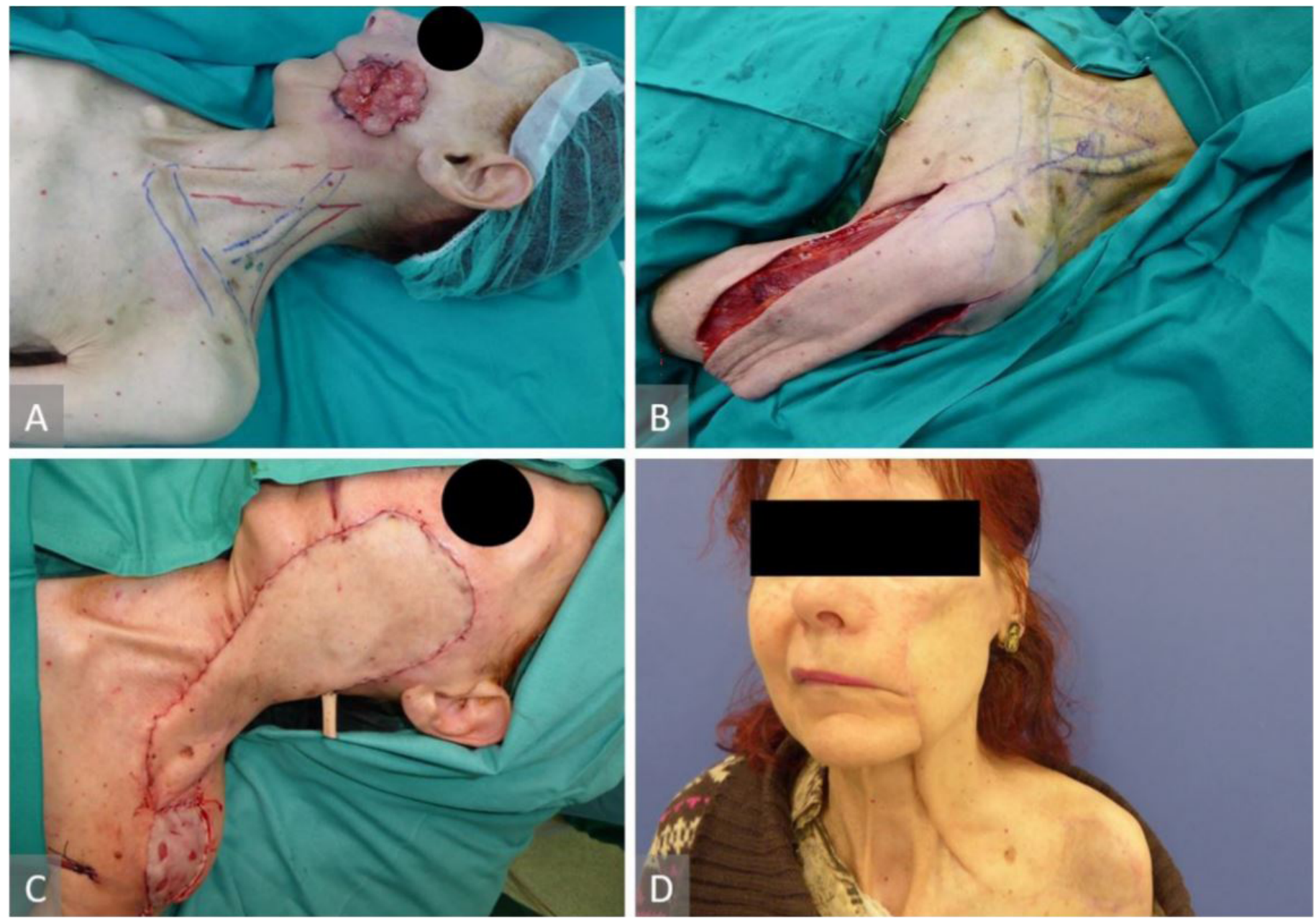

Figure 5. (A) Basal cell carcinoma in the left cheek. (B) Vascular pedicle marked and flap raised. (C) Flap inset and donor site closed with a split-thickness skin graft. (D) Six-month postoperative result.

From the literature review of supraclavicular flaps for head and neck reconstruction in PubMed search engine, 26 articles [1,2,4,11$17,19,20,23-26,28,29,31,33-40]$ were found that had used supraclavicular flaps for head and neck reconstruction and had clearly stated the length of flaps and their rate of necrosis (Table 2). The rate of necrosis varied according to the size of the flaps, and only a few of the published articles clearly associated the rate of necrosis with the definite length of the flaps.

The following articles have discussed the relationship between the length of the supraclavicular flap and distal necrosis. Ismail et al., in a study that involved 20 supraclavicular flaps ranged from $16 \mathrm{~cm}$ to $25 \mathrm{~cm}$ in length (mean $21.7 \mathrm{~cm}$ ), reported that 7 flaps (35\%) showed partial distal necrosis, either in the form of superficial epidermolysis in 5 cases or full thickness necrosis of the distal two centimeters in 2 cases. They also reported that in all their cases with distal necrosis, the flaps were $23 \mathrm{~cm}$ or more in length [31]. Ismail et al. recommended that supraclavicular flaps longer than $22 \mathrm{~cm}$ were not harvested immediately, and they recommended modification procedures such as flap expansion before harvesting [31]. Similarly, Kokot et al., in a study that involved 45 flaps with a mean length of $21.4 \mathrm{~cm}$, reported that the flap length greater than 22 $\mathrm{cm}$ significantly correlated with flap necrosis [19]. In a different article, Vinh et al. reported that a unilateral supraclavicular flap with an average size of $22 \times 10 \mathrm{~cm}$ can be elevated safely [23]. Loghmani et al. in a study with 41 flaps, where the range of flap size was $18 \pm 6 \mathrm{~cm}$ in length with 3 cases of distal necrosis, had also found that the supraclavicular flap could be safely elevated, provided it was within $20 \times 10 \mathrm{~cm}$ [36]. On the other hand, Telang et al.'s study found that the supraclavicular flap could be safely elevated within the dimensions of $20 \times 10 \mathrm{~cm}$, and the use of tissue expansion greatly amplified the total area available [37]. The results in the above discussed 5 articles strongly support our results that the flaps of $23 \mathrm{~cm}$ and above correlate with distal necrosis.

Nevertheless, the results of a published article by Kokot et al. contradict with the findings of the above-mentioned papers. They had used 22 supraclavicular artery flaps ranging $16-28 \mathrm{~cm}$ in length (mean length of $21.8 \mathrm{~cm}$ ) with partial skin flap necrosis occurred in 2 patients. In this article, it was reported that no statistical correlation was found between flap necrosis and flap length [35].

In our study, the effect of the modification procedures (the delay and the tissue expansion) clinically was not clear on the survival of the distal end of the flaps, but apparently, the expansion procedures helped in closing the flap donor sites directly up to $11 \mathrm{~cm}$ width.

The limitation of this study was about the number of flaps and, in particular, the number of modification procedures performed for the flaps. Therefore, in the future, a study with a larger sample size is recommended to achieve more reliable clinical and unbiased statistical results for modification procedures in terms of their effect on the survival length of the supraclavicular flap.

\section{Conclusion}

Correct knowledge of the relation between the length of the flap and the magnitude of the distal necrosis is essential in reconstructive surgery to avoid necrosis of the distal margin of the flap. The distal survival of the supraclavicular artery island flap is reliable up to $22 \mathrm{~cm}$, but the flaps above that size will increase the risk of distal necrosis with or without modification procedures. 
Table 2. Review of Articles on the Number of the Flaps, Length of the Flaps in Centimeters, and Number of Distal Flap Necrosis

\begin{tabular}{|c|c|c|c|}
\hline Article & Number of Flaps & Length of Flap, Range or Mean $(\mathrm{cm})$ & Number of Flap with Distal Necrosis \\
\hline Ismail et al., 2016 [31] & 20 & $25-16$ & 2 \\
\hline Margulis et al., 2017 [25] & 16 & $20-35$ & 1 \\
\hline Chen et al., 2016 [33] & 12 & $12-20$ & None \\
\hline Zhang et al., 2015 [39] & 10 & $8-12$ & 2 \\
\hline Yang et al., 2015 [26] & 16 & $12-22$ & None \\
\hline Emerick et al., 2014 [15] & 16 & 6 to 15 (average 10.3) & 2 \\
\hline Yang et al., 2014 [38] & 20 & $23-20$ & None \\
\hline Kokot et al., 2014 [35] & 22 & 16-28 (average 21.8) & 2 \\
\hline Kokot et al., 2013 [19] & 45 & 15-28 (average 21.4) & 8 \\
\hline Loghmani et al., 2013 [36] & 41 & $12-24$ & 3 \\
\hline Chen et al., 2010 [34] & 24 & $8-12$ & None \\
\hline You et al., 2013 [29] & 11 & $10-12$ & None \\
\hline Alves et al., 2012 [17] & 47 & 21-26.4 (average 24.4) & 7 \\
\hline Vinh et al., 2009 [23] & 103 & Average 21 & 4 \\
\hline Chiu et al., 2010 [1] & 20 & $18-21$ & None \\
\hline Chiu et al., 2009 [2] & 18 & Average 20 & 1 \\
\hline Pallua et al., 1997 [11] & 8 & $20-30$ & None \\
\hline Telang et al., 2009 [37] & 9 & $8-6$ & 2 \\
\hline Rashid et al., 2006 [20] & 27 & $18-24$ & None \\
\hline Balakrishnan et al., 2012 [24] & 16 & $20-35$ & 1 \\
\hline Epps et al., 2011 [16] & 10 & $7-20$ & None \\
\hline Pallua et al., 2008 [12] & 18 & $12-20$ & 2 \\
\hline Vinh et al., 2007 [40] & 32 & $11-24$ & 3 \\
\hline Di Benedetto et al., 2005 [14] & 26 & $12-35$ & 2 \\
\hline Pallua et al., 2005 [13] & 16 & $14-30$ & None \\
\hline Pallua et al., 2000 [4] & 29 & Average 22 & None \\
\hline
\end{tabular}

\section{Article Information}

* Correspondence: Hemin Sheriff, MD, PhD

Department of Surgery, College of Medicine, University of Sulaimani,

Sulaymaniyah, Iraq.

Email: hemin_sheriff@hotmail.co.uk

Received: Dec. 30, 2017; Accepted:Jun. 28, 2018; Published: Nov. 12, 2018

DOI: 10.24983/scitemed.imj.2018.00089

Copyright (C 2018 The Author (s). This is an open-access article distributed under the terms of the Creative Commons Attribution 4.0 International License (CC-BY).

Funding: None

\section{Conflict of Interest: None}

Informed Consent: Informed consents were obtained from the patients.

\section{Keywords}

Distal end necrosis; head and neck reconstruction; supraclavicular flap.

\section{References}

1. Chiu ES, Liu PH, Baratelli R, Lee MY, Chaffin AE, Friedlander PL. Circumferential pharyngoesophageal reconstruction with a supraclavicular artery island flap. Plast Reconstr Surg 2010;125(1):161-166.

2. Chiu ES, Liu PH, Friedlander PL. Supraclavicular artery island flap for head and neck oncologic reconstruction: indications, complications, and outcomes. Plast Reconstr Surg 2009;124(1):115-123.

3. Sands TT, Martin JB, Simms E, Henderson MM, Friedlander PL, Chiu ES. Supraclavicular artery island flap innervation: anatomical studies and clinical implications. J Plast Reconstr Aesthet Surg 2012;65(1):6871.

4. Pallua N, Noah EM. The tunneled supraclavicular island flap: an optimized technique for head and neck reconstruction. Plast Reconstr Surg 2000;105(3):842-851.

5. Wood-Smith D, Porowski PC. Nursing Care of the Plastic Surgery Patient. St. Louis:C V Mosby, 1967.

6. Marck KW. A history of noma, the "Face of Poverty". Plast Reconstr Surg 2003;111(5):1702-1707.

7. Marck KW, DeBruikin HP, Schmid F, Meixner J, Van Wijhe M, Van Poppelen RH. Noma: The Sokoto approach. Eur J Plastic Surg 1998;21:277-281. 
8. Hartman EH, Van Damme PA, Sauter $\mathrm{H}$, Suominen $\mathrm{SH}$. The use of the pedicled supraclavicular flap in noma reconstructive surgery. Plast Reconstr Surg 2006;59(4):337-342.

9. Lamberty B, Cormack G. Misconceptions regarding the cervico-humeral flap. Br J Plast Surg 1983;36(1):60-63.

10. Chan JW, Wong C, Ward K, Saint-Cyr M, Chiu ES. Three-and four-dimensional computed tomographic angiography studies of the supraclavicular artery island flap. Plast Reconstr Surg 2010;125(2):525531.

11. Pallua N, Machens H-G, Rennekampff O, Becker M, Berger A. The fasciocutaneous supraclavicular artery island flap for releasing postburn mentosternal contractures. Plast Reconstr Surg 1997;99(7):1878-1884.

12. Pallua N, Demir E. Postburn head and neck reconstruction in children with the fasciocutaneous supraclavicular artery island flap. Ann Plast Surg 2008;60(3):276-282.

13. Pallua N, Von Heimburg D. Pre-expanded ultra-thin supraclavicular flaps for (full-) face reconstruction with reduced donor-site morbidity and without the need for microsurgery. Plast Reconstr Surg 2005;115(7):1837-1844.

14. Di Benedetto G, Aquinati A, Pierangeli M, Scalise A, Bertani A. From the "charretera" to the supraclavicular fascial island flap: revisitation and further evolution of a controversial flap. Plast Reconstr Surg 2005;115(1):70-76.

15. Emerick KS, Herr MW, Lin DT, Santos F, Deschler DG. Supraclavicular artery island flap for reconstruction of complex parotidectomy, lateral skull base, and total auriculectomy defects. JAMA Otolaryngol Head Neck Surg 2014;140(9):861-866.

16. Epps MT, Cannon CL, Wright MJ, et al. Aesthetic restoration of parotidectomy contour deformity using the supraclavicular artery island flap. Plast Reconstr Surg 2011;127(5):1925-1931.

17. Alves HR, Ishida LC, Ishida LH, et al. A clinical experience of the supraclavicular flap used to reconstruct head and neck defects in latestage cancer patients. J Plast Reconstr Aesthet Surg 2012;65(10):13501356.

18. Wirtz NE, Khariwala SS. Update on the supraclavicular flap. Curr Opin Otolaryngol Head Neck Surg 2017;25(5):439-444.

19. Kokot N, Mazhar K, Reder LS, Peng GL, Sinha UK. The supraclavicular artery island flap in head and neck reconstruction: applications and limitations. JAMA Otolaryngol Head Neck Surg 2013;139(11):12471255.

20. Rashid M, Zia-ul-Islam M, Bhatti AM. The 'expansile' supraclavicular artery flap for release of post-burn neck contractures. J Plast Reconstr Aesthet Surg 2006;59(10):1094-1101.

21. Pallua N, Wolter TP. Moving forwards: the anterior supraclavicular artery perforator (a-SAP) flap: a new pedicled or free perforator flap based on the anterior supraclavicular vessels. J Plast Reconstr Aesthet Surg 2013;66(4):489-496.

22. Tayfur V, Magden O, Edizer M, Menderes A. Supraclavicular artery flap. J Craniofac Surg 2010;21(6):1938-1940.

23. Vinh VQ, Van Anh T, Ogawa R, Hyakusoku H. Anatomical and clinical studies of the supraclavicular flap: analysis of 103 flaps used to reconstruct neck scar contractures. Plast Reconstr Surg 2009;123(5):1471-1480.

24. Balakrishnan TM, Sivarajan N. Anatomical study of supraclavicular perforator artery and its clinical application as sensate supraclavic- ular artery propeller flap in the reconstruction of post burns scar contracture neck. Indian J Sci Technol 2012;5(8):3137-3141.

25. Margulis A, Agam K, Icekson M, Dotan L, Yanko-Arzi R, Neuman R. The expanded supraclavicular flap, prefabricated with thoracoacromial vessels, for reconstruction of postburn anterior cervical contractures. Plast Reconstr Surg 2007;119(7):2072-2077.

26. Yang $Y$, Ren J, Pang $X$, Bai $Y$, Yuan W, Xu W. [Reconstruction of facial and cervical scar with the expanded supraclavicular island flaps]. Zhonghua Zheng Xing Wai Ke Za Zhi 2015;31(1):11-13 [Article in Chinese].

27. Khouri RK, Ozbek MR, Hruza GJ, Young VL. Facial reconstruction with prefabricated induced expanded (PIE) supraclavicular skin flaps. Plast Reconstr Surg 1995;95(6):1007-1015.

28. Vinh VQ, Ogawa R, Iwakiri I, Hyakusoku H, Tanuma K. Clinical and anatomical study of cervicopectoral superthin flaps. Plast Reconstr Surg 2007;119(5):1464-1471.

29. You Y-H, Chen W-I, Zhang D-M. Closure of large oropharyngocutaneous fistulas using a folded extensive supraclavicular fasciocutaneous island flap. J Oral Maxillofac Surg Med Pathol 2013;25(4):310-313.

30. Heitland AS, Pallua N. The single and double-folded supraclavicular island flap as a new therapy option in the treatment of large facial defects in noma patients. Plast Reconstr Surg 2005;115(6):1591-1596.

31. Ismail H, Elshobaky A. Supraclavicular artery perforator flap in management of post-burn neck reconstruction: clinical experience. Ann Burns Fire Disasters 2016;29(3):209.

32. Ortiz CL, Carrasco AV, Torres AN, Sempere LN, Mendoza MM. Supraclavicular bilobed fasciocutaneous flap for postburn cervical contractures. Burns 2007;33(6):770-775.

33. Chen B, Song H, Xu M, Gao Q. Reconstruction of cica-contracture on the face and neck with skin flap and expanded skin flap pedicled by anterior branch of transverse cervical artery. J Craniomaxillofac Surg 2016;44(9):1280-1286.

34. Chen W-L, Zhang D-M, Yang Z-H, et al. Extended supraclavicular fasciocutaneous island flap based on the transverse cervical artery for head and neck reconstruction after cancer ablation. J Oral Maxillofac Surg 2010;68(10):2422-2430.

35. Kokot N, Mazhar K, Reder LS, Peng GL, Sinha UK. Use of the supraclavicular artery island flap for reconstruction of cervicofacial defects. Otolaryngol Head Neck Surg 2014;150(2):222-228.

36. Loghmani S, Eidy M, Mohammadzadeh M, Loghmani A, Raigan F. The supraclavicular flap for reconstruction of post-burn mentosternal contractures. Iranian Red Crescent Medical Journal 2013;15(4):292.

37. Telang $\mathrm{P}$, Jagannathan $\mathrm{M}$, Devale M. A study of the use of the supraclavicular artery flap for resurfacing of head, neck, and upper torso defects. Indian J Plast Surg 2009;42(1):4.

38. Yang Z, Hu C, Li Y, et al. Pre-expanded cervico-acromial fasciocutaneous flap based on the supraclavicular artery for resurfacing postburn neck scar contractures. Ann Plast Surg 2014;73:S92-S98.

39. Zhang B, Yan D, Zhang Y, Zhang X, Wan H. [Clinical experience with the supraclavicular flap to reconstruct head and neck defects]. Zhonghua Er Bi Yan Hou Tou Jing Wai Ke Za Zhi 2015;50(6):468-472. [Article in Chinese].

40. Vinh VQ, Ogawa R, Van Anh T, Hyakusoku H. Reconstruction of neck scar contractures using supraclavicular flaps: retrospective study of 30 cases. Plast Reconstr Surg 2007;119(1):130-135. 